Analisis Direct Dperating CastDalam Sistem Pendukung Keputusan Penentuan Tipe Pesawat Terbang Untuk Pembukaan Rute Baru Penerbangan

\title{
ANALISIS DIRECT OPERATING COST DALAM SISTEM PENDUKUNG KEPUTUSAN PENENTUAN TIPE PESAWAT TERBANG UNTUK PEMBUKAAN RUTE BARU PENERBANGAN
}

\author{
Rina Widiastuti, Anton Setiawan Hawibowo, Yuliani Indrianingsih \\ Jurusan Teknik Informatika \\ Sekolah Tinggi Teknologi Adisutjipto Yogyakarta \\ informatika@stta.ac.id
}

\begin{abstract}
The more commercial flights now, will be result more the number of aircraft operated and the competition to become the airline can keep operating even more difficult. Some airline companies can not compete with other companies, has gone out of business. This is one of them caused by the inaccuracy of an airline's decision in the selection of aircraft types.

Type of aircraft used for flight routes should be tailored to the needs so that it can provide benefits to the company. The selection of planes is determined based on market analysis with indicators of the number of passengers, aircraft, engineering aspects of the commercial aspects or the operational costs of aircraft and competitor analysis. Aircraft direct operating costs are costs directly related to the operator of the aircraft in flight routes. Direct operating cost is very influential in the selection of aircraft types that will be used. On certain conditions the determination of the decision must be taken quickly, in which one of the conditions is the availability of relevant information.

Information is the output system that can be utilized by the parties in need. Decision support system to determine the type of aircraft is a computer application that provides output in the form of aircraft operating cost information that can support managers in making decisions determining the effective fleet at the new flight routes.
\end{abstract}

Keywords: DSS, Direct Operating Costs, New Flight Routes

\section{Pendahuluan}

Marakya penerbangan komersial (airlines) saat ini, telah menimbulkan persaingan yang hebat pada perusahaan penerbangan. Perusahaan penerbangan yang tidak dapat bersaing dengan perusahaan lain, telah gulung tikar. Hal tersebut salah satunya disebabkan oleh tidak tepatnya keputusan suatu airline didalam pemilihan tipe pesawat. Dalam kondisi tertentu segala keputusan harus diambil dengan cepat, dimana salah satu syaratnya adalah ketersediaan informasi yang relevan. Salah satu komponen dari manajemen airline yang cukup vital adalah masalah manajemen rute dan penentuan armada yang dipakai.

Analisis biaya operasional merupakan salah satu pertimbangan dalam menentukan dan merencanakan armada yang akan dioperasikan oleh suatu perusahaan penerbangan. Analisis biaya operasional pesawat, yang meliputi biaya operasional langsung dan baya operasional tidak langsung. Analisis biaya operasional langsung memiliki pengaruh sangat besar dalam penentuan tipe pesawat yang akan digunakan untuk melayani rute penerbangan, karena berhubungan langsung dengan total biaya yang dikeluarkan oleh masing-masing pesawat. Sistem dapat 
memberikan informasi dengan cepat dan relevan dibandingkan perhitungan manual sehingga dapat meningkatkan kualitas keputusan.

Adanya pemilihan jenis pesawat yang tepat, maka pesawat yang terbang tidak sia-sia karena seat yang tersedia dapat terisi sesuai dengan kapasitasnya, sehingga airline akan mendapatkan keuntungan sesuai dengan yang diharapkan dan terhindar dari kebangkrutan.

\section{Sistem Pendukung Keputusan}

Sistem Pendukung Keputusan (SPK) atau dalam bahasa inggrisnya dikenal dengan DSS (Decission Support System) merupakan sistem informasi interaktif yang menyediakan informasi, pemodelan, dan pemanipulasian data. Sistem ini digunakan untuk membantu pengambil keputusan dalam situasi semiterstruktur dan situasi yang tidak terstruktur, dimana tak seorang pun tahu secara pasti bagaimana keputusan seharusnya dibuat (Alter, 2002).

SPK lebih ditujukan untuk mendukung manajemen dalam melakukan pekerjaan yang bersifat analitis dalam situasi yang kurang terstruktur dan dengan kriteria yang kurang jelas. SPK tidak dimaksudkan untuk mengotomatisasikan pengambilan keputusan, tetapi memberikan perangkat interaktif yang memungkinkan pengambil keputusan untuk melakukan berbagai analisis menggunakan model-model yang tersedia

\section{Direct Operating Cost}

Merupakan seluruh biaya yang berhubungan langsung dengan operasional pesawat dan tergantung kepada jenis pesawat udara yang dioperasikan dan akan berubah untuk jenis pesawat yang berbeda. Direct operating cost ini dapat dikelompokkan menjadi :

1. Flight operation cost adalah biaya yang harus dikeluarkan sehubungan dengan pengoperasian pesawat tersebut. Komponen biaya ini meliputi beberapa unsur yaitu biaya awak pesawat (air crew), biaya bahan bakar, biaya leasing, biaya asuransi

2. Maintenance cost, biaya yang harus dikeluarkan akibat adanya perawatan pesawat. Terdiri dari biaya tenaga kerja dan biaya material

3. Depresiasi dan amortisasi. Depresiasi merupakan biaya akibat turunnya nilai nominal atau harga pesawat seiring dengan berjalannya waktu sejak produk tersebut keluar. Sedangkan amortisasi merupakan penyisihan uang secara berkala untuk biaya-biaya seperti pelatihan awak kabin, biaya pengembangan dan pra-operasi yang berhubungan dengan pengembangan rute atau penggunaan pesawat baru.

\section{Metode Penelitian}

Penelitian ini menggunakan metode penelitian :

1. Metode Pengumpulan Data. Merupakan metode yang dilakukan untuk mengumpulkan data-data pendukung pembuatan aplikasi. Metode-motode pengumpulan data yang digunakan dalam penelitian ini yaitu : Metode Dokumentasi, Metode Wawancara ( interview ) dan Metode Kepustakaan. Hasil dari pengumpulan data ini akan menjadi data yang akan dianalisis.

2. Metode Perancangan dan Pembuatan Teknologi. Metode ini dilakukan untuk merancang dan membuat implementasi sistem pendukung keputusan sesuai dengan data-data yang telah dikumpulkan.

3. Metode Penerapan Teknologi. Merupakan metode untuk menerapkan data yang ada pada aplikasi sistem pendukung keputusan.

4. Metode Evaluasi. Metode evaluasi untuk mengetahui kelemahan-kelemahan dari implementasi tersebut. Evaluasi ini dapat untuk perkembangan teknologi selanjutnya. 


\section{Perancangan Antar muka Spesifikasi Hardware}

Hardware atau perangkat keras merupakan semua peralatan fisik komputer. Sistem perangkat keras ini terdiri dari unit input, proses, dan output. Beberapa kebutuhan perangkat keras yang digunakan dalam pembuatan sistem ini adalah :

1. Processor Intel Pentium Dual Core

2. Motherboard Biostar P4TGV

3. RAM $1 \mathrm{~GB}$

4. Harddisk $160 \mathrm{~GB}$

5. CD ROM

6. Keyboard, Mouse, monitor standar

\section{Spesifikasi Software}

\section{Sistem Operasi}

Sistem operasi yang digunakan adalah Windows XP SP 2

2. Bahasa Pemrograman Borland Delphi 7.0

3. Database

Database yang digunakan adalah MySQL Database 5.0.24a

4. Mysql Connector ODBC 5.1.5

\section{Diagram Alir Data}

Diagram Alir Data yang disingkat DAD atau DFD (Data Flow Diagram) merupakan suatu model logika data atau proses yang dibuat untuk menggambarkan dari mana asal data dan ke mana tujuan data yang keluar dari sistem, dimana data disimpan, proses apa yang menghasilkan data tersebut dan interaksi antara data yang tersimpan dan proses yang dikenakan pada data tersebut.

\section{Diagram Konteks}

Dibawah ini merupakan diagram konteks untuk sistem pendukung keputusan. Entitas terdiri dari User dan database. User mengisikan data bandara, data engine, data pesawat dan data variabel rute ke sistem, kemudian sistem akan menyimpannya ke database. Dari database sistem akan memberikan laporan mengenai total biaya operasional langsung masing-masing pesawat yang telah dihitung.. Diagram konteks ditunjukan pada gambar 1.

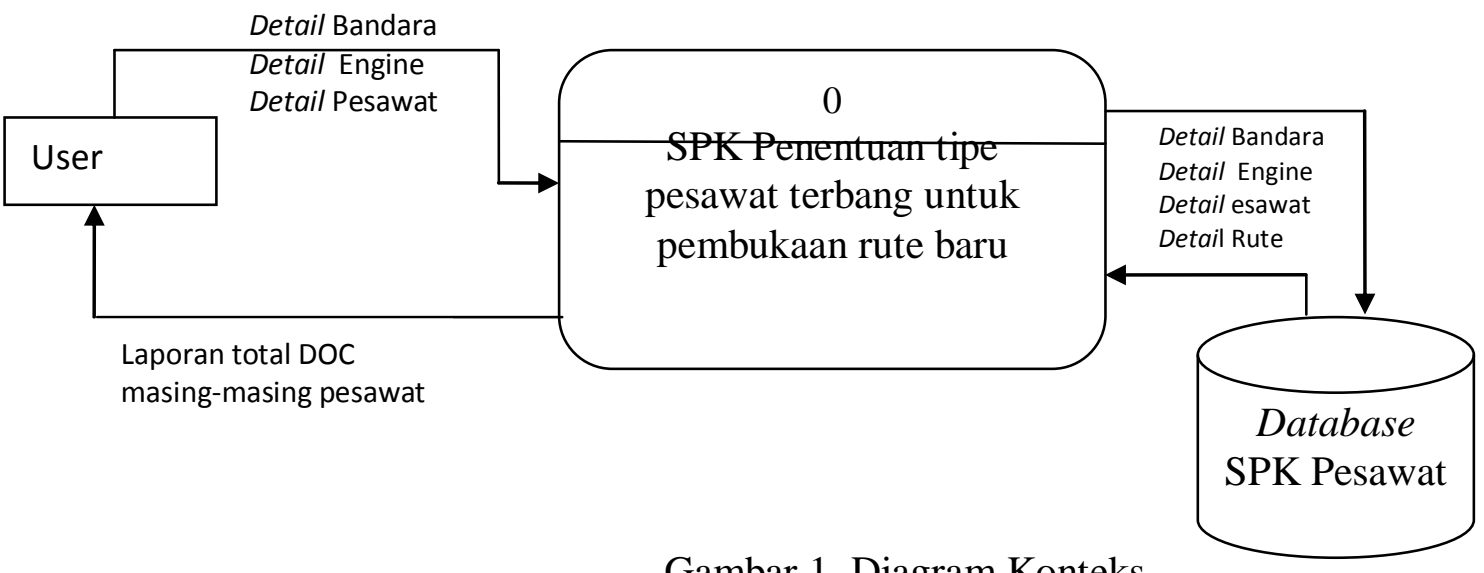

Gambar 1 Diagram Konteks 


\section{Diagram Level 1}

Di bawah ini adalah diagram level 1 yang menggambarkan proses dari dataflow diagram. Proses yang terjadi adalah isi data yaitu user mengisi data bandara, engine, pesawat yang disimpan dalam data store 'data', isi data var rute yaitu proses untuk mengisikan data variable rute yang disimpan dalam store 'rute', DOC pesawat yaitu proses pengolahan data untuk menghitung DOC dari masing-masing pesawat, lihat data SPK yaitu proses untuk melihat datadata yang tersimpan di database.

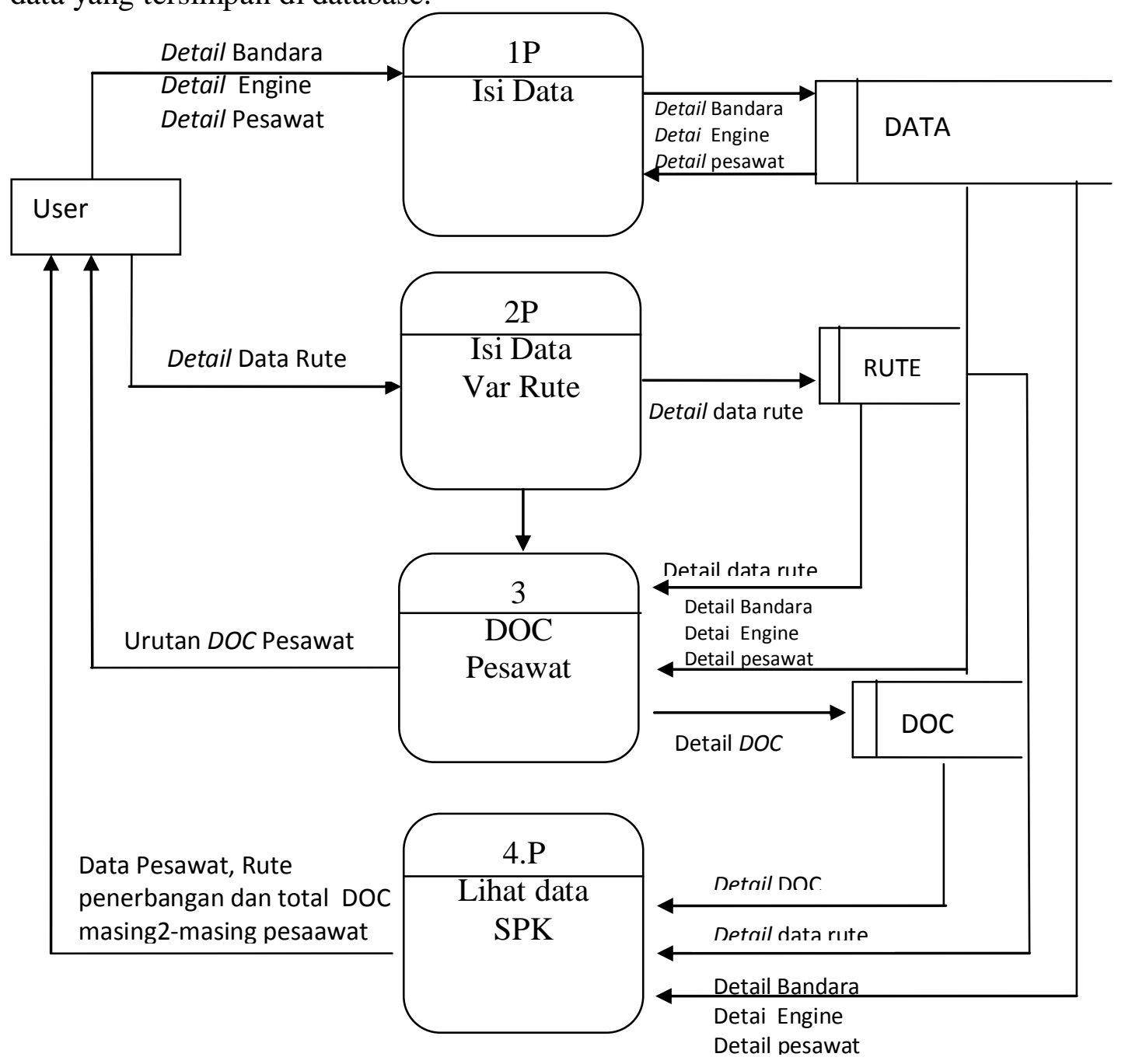

Gambar 2 Diagram Alir Data (DAD) Level 1

\section{Diagram Rinci Proses Pengambilan Keputusan}

Diagram rinci adalah diagram yang menguraikan apa yang ada di dalam diagram level 1 atau diagram di atasnya Diagram rinci dalam sistem penjualan dijelaskan pada proses transaksi penjualan. (Ladjamudin, 2005). Proses DOC pesawat dapat dapat diuraikan lagi menjadi proses simpan keputusan dan proses cetak data keputusan. Gambar 3 DAD level 2 pada poses DOC pesawat : 


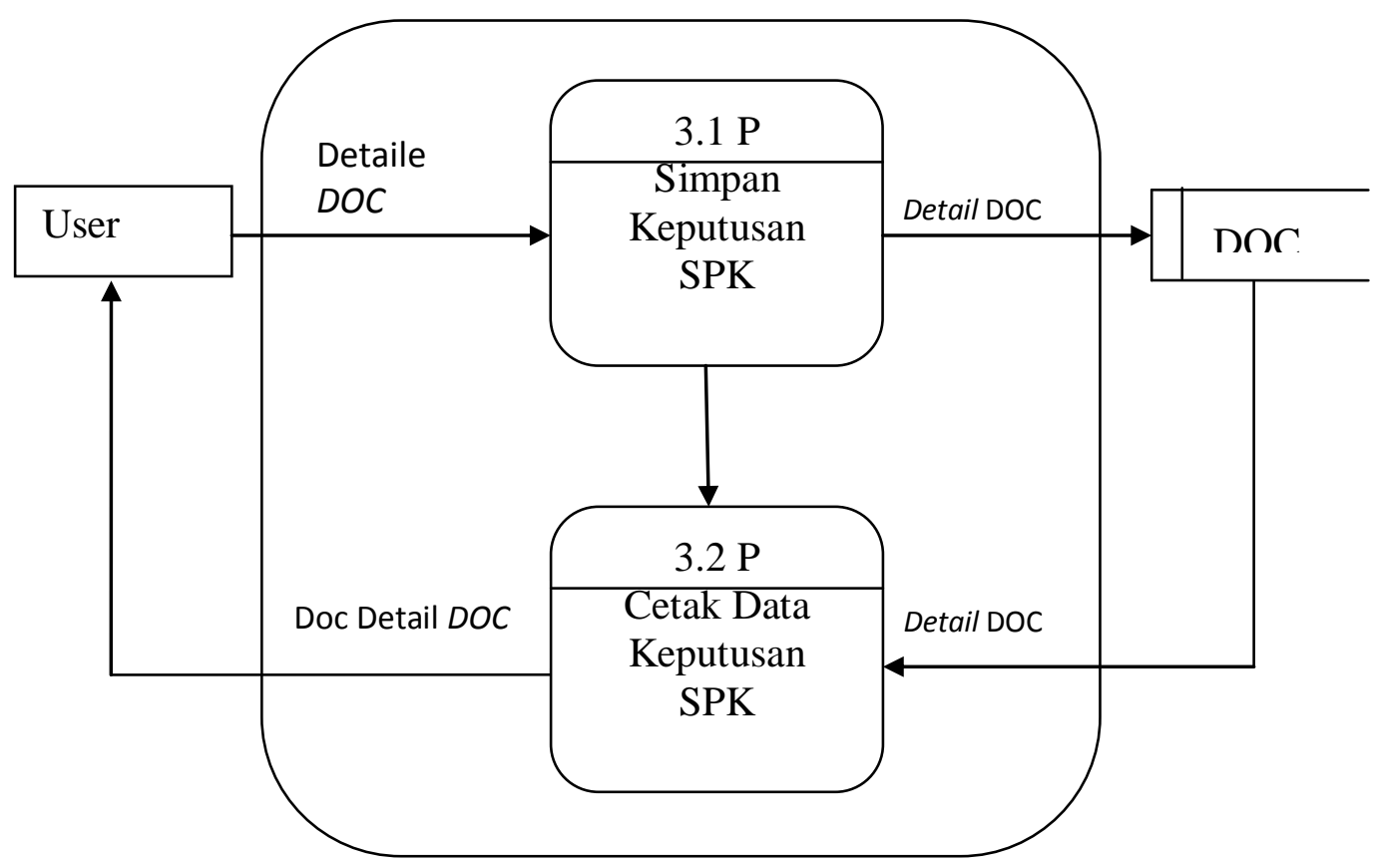

Gambar 3 DAD Level 2 Untuk Proses DOC Pesawat

\section{Implementasi dan Analisa}

Dalam melakukan uji coba, penelitian ini menggunakan data rute penerbangan Jogjakarta-Makassar. Dengan memperhatikan kondisi landasan dari asing-masing bandara maka dipilih beberapa alternatif tipe pesawat seperti pada table 1 .

Tabel 1 Karakteristik Pesawat Terbang untuk Rute Jogjakarta-Makasar

\begin{tabular}{|l|c|c|c|c|c|c|c|}
\hline \multirow{2}{*}{ Pesawat } & \multicolumn{2}{|c|}{ Performance } & \multicolumn{3}{c|}{ Aircraft Weight } & \multicolumn{2}{c|}{$\begin{array}{c}\text { Panjang landasan } \\
\text { (meter) }\end{array}$} \\
\cline { 2 - 9 } & $\begin{array}{l}\text { Speed } \\
(\mathrm{km} / \mathrm{h})\end{array}$ & $\begin{array}{l}\text { Max } \\
\text { Range }\end{array}$ & Seats & MTOW & MLW & Take Off & Landing \\
\hline ATR-42-500 & 563 & 2.965 & 60 & 41.005 & 40.344 & 1.165 & 1.126 \\
\hline SAAB 2000 & 656 & 2.868 & 60 & 50.251 & 48.488 & 1.290 & 1.250 \\
\hline Bombardier Dash8-300 & 532 & 2.034 & 60 & 42.989 & 41.876 & 1.085 & 1.006 \\
\hline
\end{tabular}

\section{Analisis Direct Operating Cost Manual}

Analisis manual Direct Operating Cost adalah analisis perhitungan total biaya operasional langsung masing-masing pesawat yang melayani rute penerbangan tersebut yang dihitung secara manual. Dalam perhitungannya menggunakan pembulatan desimal. Hasil perhitungan Direct Operating Cost secara manual.

Tabel 2 Direct Operating Cost (DOC)

\begin{tabular}{|c|c|c|c|c|c|}
\hline Tipe pesawat & FOC (US\$) & Perawatan (US\$) & DOC/trip & DOC/jam & $\begin{array}{c}\text { Depreciation } \\
\text { (tahun) }\end{array}$ \\
\hline
\end{tabular}




\begin{tabular}{|c|c|c|c|c|c|}
\hline ATR-42-500 & $2.677,26$ & 140,41 & $2.817,67$ & 1458,34 & 635.550 \\
\hline SAAB 2000 & $2.368,25$ & 179,24 & 2547,49 & $1.460,75$ & 712.585 \\
\hline B.Dash 8 Q300 & $1.553,51$ & 145,29 & 1698,8 & 845,17 & 527.297 \\
\hline
\end{tabular}

\section{Analisis Direct Operating Cost Menggunakan Sistem}

Analisis Direct Operating Cost secara sistem yaitu analisis total biaya operasional langsung pesawat berdasarkan hasil perhitungan sistem yang dibuat. Sistem akan memberikan informasi mengenai total Direct Operating Cost masing-masing pesawat dan detail biaya komponen DOC.

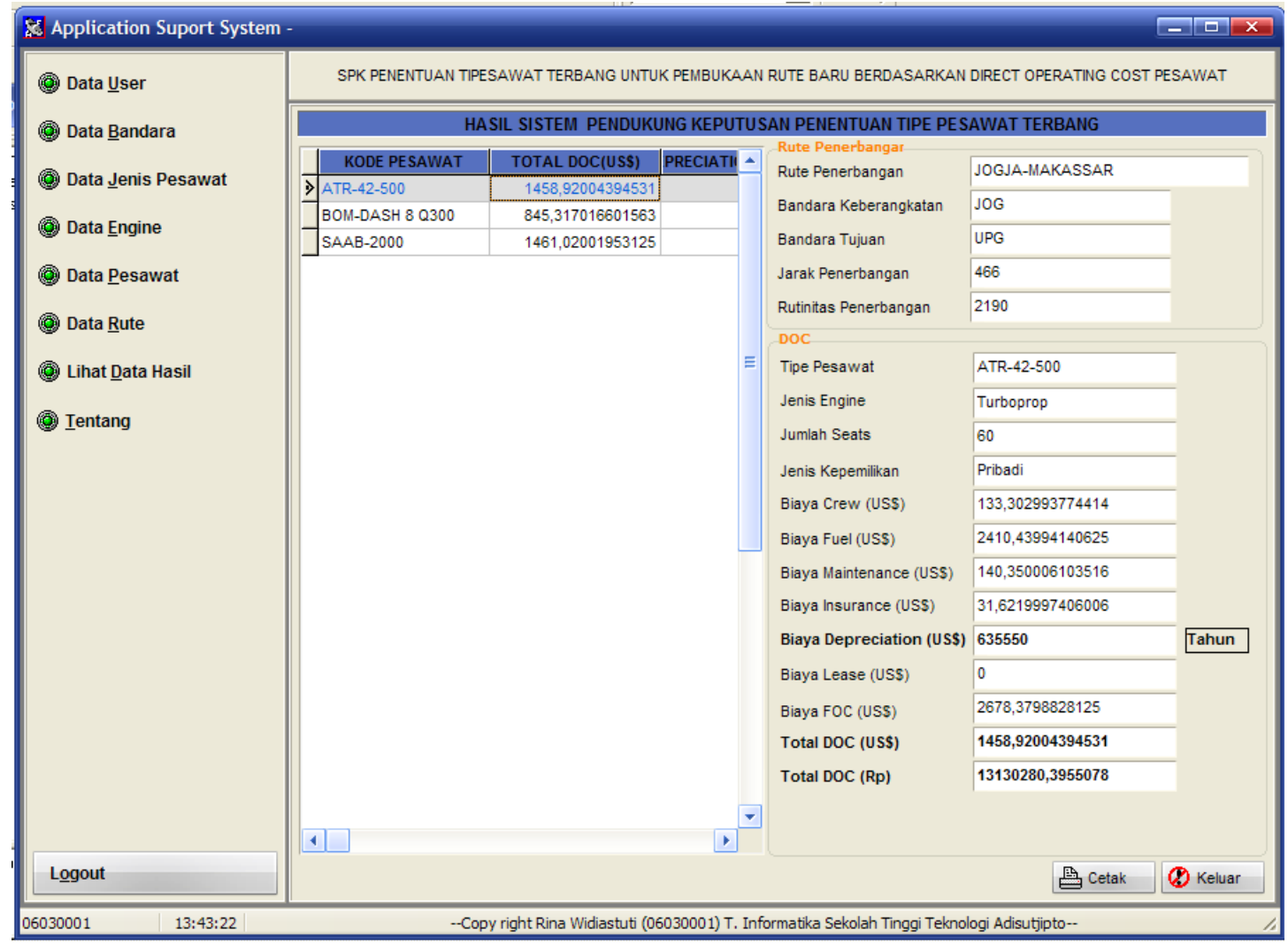

Gambar 4 Antarmuka Sistem Hasil DOC

\section{Analisis Direct Operating Cost Secara Manual Dan Sistem}

Perbedaan hasil perhitungan $D O C$ secara manual dengan perhitungan menggunakan aplikasi tidak terlalu signifikan. Perhitungan menggunakan aplikasi tidak menggunakan pembulatan desimal, sedangkan perhitungan manual menggunakan fungsi pembulatan penuh keatas jika angka sama dengan atau lebih dari 0,5 dan pembulatan ke bawah jika kurang dari angka 0,5 .

Hasil perhitungan $D O C$ masing-masing pesawat menunjukkan bahwa pesawat dengan tipe BOM-DASH 8 Q300 memiliki total biaya operasional langsung yang paling rendah, baik melalui perhitungan manual dan perhitungan aplikasi.

Keputusan dari komponen DOC tipe BOM-DASH 8 Q300 adalah tipe pesawat yang efektif untuk melayani rute penerbangan Jogjakarta-Makassar, namun pada kenyataanya dilapangan tipe pesawat tersebut belum tentu dipilih untuk melayani rute penerbangan tersebut 
karena masih ada komponen lain yang menjadi pertimbangan dalam penentuan tipe pesawat tersebut. Beberapa pertimbangan lain yang digunakan sebagai parameter dalam pemilihan jenis pesawat diantaranya adalah (1) karakteristik pesawat udara, yang meliputi prestasi pesawat udara (aircraft performance), berat pesawat (aircraft weight), kehandalan (reliability) dan keterawatan (maintainability), profil terbang, sertifikasi, peralatan dan fasilitas pendukung, perbandingan pesawat udara, (2) analisis biaya operasional pesawat, yang meliputi biaya operasional langsung dan baya operasional tidak langsung, (3) penggunaan dan jadwal penerbangan (4) analisis ekonomi dan finansial, (5) pendanaan pengadaan pesawat, dan (6) kecenderungan pembelian.

\section{Kesimpulan}

Dari hasil analisis yang telah diuraikan, maka penelitian yang telah dilakukan ini memiliki kesimpulan sebagai berikut :

1. Pengambilan keputusan penentuan tipe pesawat terbang untuk pembukaan rute baru tidak dapat dilakukan hanya dengan melihat komponen DOC saja, tetapi terdapat beberapa komponen lain yang harus dijadikan pertimbangan diantaranya : indirect operating cost, analisa teknik pesawat, analisa pasar, analisa pesaing.

2. Aplikasi SPK ini memberikan informasi mengenai total biaya operasional pesawat terbang . Informasi tersebut dapat dijadikan acuan dalam perhitungan laba rugi perusahaan dengan pembukaan rute baru tersebut.

Selain Kesimpulan, peneliatian ini juga memiliki saran yang dapat digunakan untuk pengembangan dan penelitian selanjutnya yang terkait dengan penelitian ini, saran tersebut antara lain :

1. Aplikasi penentuan tipe pesawat terbang tidak hanya berdasarkan biaya operasional langsung pesawat tetapi berdasarkan biaya tidak langsung dan analisa pasar.

2. Menggunakan peta digital untuk menentuan jarak penerbangan, sehingga jarak penerbangan tidak diinputkan manual pada sistem.

3. Rumus perhitungan disesuaikan dengan diupdate lagi.

\section{Daftar Pustaka}

Harris Franklin D., 2005, An Economic Model of U.S. Airline Operating Expenses, NASA Ames Research Center, California : University of Maryland.

Jogiyanto HM., 2005, Analisis dan Desain Sistem Informasi: Pendekatan Teori dan Praktek Aplikasi Bisnis, Yogyakarta : CV. Andi Offset.

Ladjamudin, Al-Bahra. (2005). Analisis dan Desain Sistem Informasi, Graha Ilmu, Yogyakarta.

Nugroho, Bunafit. (2004), Database Relasional dengan MySQL, Penerbit ANDI, Yogyakarta,

Pasaribu Hisar M., 2002, Sistem Transportasi Udara, Diktat Kuliah, Bandung : Departemen Teknik Penerbangan Institut Teknologi Bandung

Sadono Mahardi, 2005, Manajemen Airline, Bandung : Departemen Teknik Penerbangan Institut Teknologi Bandung.

Compiler 
Rina Widiastuti, Anton Setiawan Hawibowo, Yuliani Indrianingsih

Turban, Efraim. E.Aronson, Jay. Liang, Ting-Peng. (2005), Decision Support Systems and Intelligent Systems (Sistem Pendukung Keputusan dan Sistem Cerdas), Penerbit ANDI, Yogyakarta,

Air Transport Association of America, 1967, ATA Cost Method, Standard Method of Estimating Comparative Direct Operating Cost Of Turbine Powered Transport Airplanes, http://adg.stanford.edu/aa241/cost/atamethod.html 